Uniwersytet Marii Curie-Skłodowskiej, Lublin

\title{
Rola referendum w powstawaniu państw po 1989 r. w Europie
}

Referendum jest jednym z narzędzi demokracji bezpośredniej, pow sprawach najbardziej istotnych dla państwa. Referenda odegrały istotną rolę w powstawaniu nowych państw po 1989 r. w Europie.

W państwach postsocjalistycznych rodzącej się demokracji politycznej przychodziło borykać się $\mathrm{z}$ wieloma trudnościami. W rozwiązywaniu złożonych problemów w wymiarze dziejowym nie było gotowych wzorców i modeli w historii tych państw, a uwarunkowania społeczno-polityczne niedawnej przeszłości ciążyły na działaniach elit politycznych ${ }^{1}$.

W krajach Europy Środkowej i Wschodniej na przełomie lat osiemdziesiątych i dziewięćdziesiątych nastąpił gwałtowny wzrost ruchów demokratycznych. Stworzenie władzy demokratycznej było podstawowym celem politycznym, jakie stawiały sobie społeczeństwa tych państw. Przy realizacji takiego celu istotnym jest, aby twórcy konstytucji dążyli do stworzenia systemu władzy zarazem efektywnej, jak i ograniczonej, a więc systemu, który skutecznie zapobiegałby możliwości wynaturzeń w kierunku dyktatury ${ }^{2}$.

W młodych demokracjach problemem, jaki się pojawił, to poszukiwanie formuły demokratycznych i efektywnych i stabilnych rządów. We wszystkich państwach stworzone zostały konstytucyjno-prawne podstawy rządów demokratycznych stworzone m.in. poprzez upowszechnienie instytucji referendum ogólnokrajowego i lokalnego oraz innych form demokracji bezpośredniej ${ }^{3}$.

1 E. Zieliński, Referendum w państwach Europy Środkowej $i$ Wschodniej, w: Referendum konstytucyjne w Polsce, red. M. T. Staszewski, D. Waniek, Warszawa 1997, s. 203.

2 S. Holmes, O metodzie zmian konstytucji w państwach Europy Środkowej i Wschodniej, „Państwo i Prawo” 1993, nr 8, s. 44-45.

3 T. Mołdawa, Konstytucjonalizm państw Europy Środkowo-Wschodniej a Europejskie standardy konstytucyjne, „Rocznik Nauk Politycznych” 2002, nr 1(4), s. 155. 
Niezależnie od uwarunkowań sytuacja taka pozwala obywatelom na włączenie się do procesu podejmowania decyzji politycznych, służy pełniejszej informacji i edukacji obywatelskiej, uczy współodpowiedzialności za sprawy publiczne, wdraża do demokracji partycypacyjnej, służy legitymizacji partii politycznych czy konkretnych decyzji. Kampanie związane z przedmiotem referendum sprawują, że nawet osoby niegłosujące są świadome przedmiotu sporu, prowadzą one, bowiem do powszechnej dyskusji nad sprawami publicznymi, co w rezultacie sprzyja wzrostowi wiedzy ${ }^{4}$.

E. Zieliński uważa, że motywy przeprowadzania referendum są bardzo różne. Zależą one od doświadczeń w przeszłości, a także od tego jaka jest sytuacja państwa, na jakim etapie transformacji się ono znajduje, jak funkcjonują konstytucyjne organy. Wyróżnia on cztery charakterystyczne motywy:

- decydowania o własnym losie narodowym;

- legitymizowanie władzy politycznej;

- konstytucjonalizacja ustrojowa;

- rozstrzyganie spraw spornych z natury ustrojowej ${ }^{5}$.

Mianem referendum niepodległościowego zwykło się określać głosowania, w których obywatele mogą wypowiadać się w kwestiach dotyczących wolności i suwerenności narodu.

Stawianie na referendum w kształtującej się demokracji politycznej państw Europy Środkowej i Wschodniej było wychodzeniem elit rządzących do narodu, co prowadziło do porozumienia i łagodzenia konfliktów społecznych. W procesie transformacji ustrojowej referendum nabrało trochę innego znaczenia. Po raz pierwszy ta forma wyrażenia woli narodu opowiadała się za uzyskaniem niepodległości. W procesie odrodzenia narodowego i państwowego referenda niepodległościowe odbyły się w krajach należących do dwóch różnych federacji radzieckiej i jugosłowiańskiej.

W latach 1990-2006 odbyły się referenda niepodległościowe w następujących państwach: Litwa, Łotwa, Estonia, Ukraina, Gruzja, Armenia, Turkmenistan, Azerbejdżan, Uzbekistan, Słowenia, Chorwacja, Bośnia i Hercegowina, Macedonia, Czarnogóra, Kosowo.

4 I. Bokszczanin, Instytucja referendum ratyfikacyjnego $w$ procesie integracji w Europie, w: Wymiar społeczny członkostwa Polski w Unii Europejskiej, red. T. Mołdawa, K. A. Wojtaszczyk, A. Szymański, Warszawa 2003, s. 369.

5 Zob. szerzej: E. Zieliński, Referendum w państwach Europy..., op. cit., s. 214-218. 
W artykule przeanalizowano referenda organizowane w latach 1991-2006 w państwach należących do federacji radzieckiej i jugosłowiańskiej.

Pierwszymi państwami, które podjęły próbę przeprowadzenia referendów były państwa bałtyckie Litwa, Lotwa i Estonia.

Deklaracje suwerenności państwowej ogłoszone w końcu 1988 i w pierwszej połowie 1989 r. przez Litwę, Łotwę i Estonię rozpoczęły pierwszą fazę walk tych republik o odzyskanie przez nie niepodległości ${ }^{6}$.

W 1991 r. władze republik Estonii, Litwy i Łotwy jeszcze pozostających pod zwierzchnictwem ZSRR, wezwały społeczeństwa do wypowiedzenia się w sprawie przywrócenia niepodległości. W głosowaniach ludność Estonii, Litwy i Łotwy wypowiedziała się za powrotem do niepodległego bytu i samodzielności państwowej.

Postanowiono ,wybić się na niepodległość”, odbudowując swe tradycyjne związki geocywilizacyjne ze Skandynawią, a jednocześnie uniezależniając się od swych uboższych, posiadających mniej rozwinięte tradycje demokratyczne, wyznających inną religię, a przy tym potężniejszych oraz ludnościowo liczniejszych sąsiadów (Rosja) ${ }^{7}$.

Litwini 9 lutego 1991 r. odpowiadali na pytanie Czy zgadzasz sie, aby Państwo Litewskie było niepodległa demokratycznq republikq. Do urn poszło 84,43 proc., za opowiedziało się 90,47 proc. Pierwsza ustawa konstytucyjna została wydana 11 lutego 1991 r. „O państwie Litewskim”, w której zaświadczono, że „naród Litwy wyrażoną suwerennie wolą raz jeszcze potwierdził swe niezłomne postanowienie w kwestii niepodległości Państwa litewskiego”; stwierdzono, że „Państwo Litewskie jest niepodległą republiką demokratyczną”, co stanowi „normę konstytucyjną Republiki Litewskiej i fundamentalną zasadę państwa"8.

Litwa jeszcze raz udowodniła, że chce być niepodległym państwem. Parlament Litwy zwrócił się do parlamentów i rządów świata z prośbą

6 K. Karski, Proces rozpadu Zwiazku Radzieckiego, Warszawa 1992, s. 5.

7 Zob.: W. Anioł, Współczesny nacjonalizm w Europie Środkowo-Wschodniej: podłoże, rodzaje napięć i reakcja instytucji regionalnych, w: Nacjonalizm. Konflikty narodowościowe w Europie Środowej $i$ Wschodniej, red. S. Helnarski, Torun 2001, s. 161; R. Kwiecień, Tożsamość Litwy, Łotwy i Estonii, Warszawa 1997, s. 19-24.

8 O. Szura, Litwa - przemiany polityczne. Dynamika systemów politycznych wybranych państw Europy Środkowej $i$ Wschodniej, red. M. Barański, Katowice 1995, s. $104-105$. 
o poparcie i nawiązanie dyplomatycznych kontaktów, a także przyjęcie Litwy w poczet członków ONZ ${ }^{9}$.

2 lutego 1990 r. Rada Najwyższa Republiki Estońskiej przyjęła „Deklarację w sprawie niezawisłości państwa”. Estończycy wypowiadali się 3 lutego 1991 r. Odpowiedzi „tak” na pytanie Czy chcesz odbudowy samodzielności i niezależności państwowej Republiki Estonii udzieliło 77,8 proc. głosujących. Frekwencja wyniosła 82,96 proc. Na Łotwie głosowanie odbyło się również 3 lutego 1991 r. Uczestniczyło w nim 87,5 proc. uprawnionych, $\mathrm{z}$ czego za niepodległym państwem było 73,68 proc. głosujących ${ }^{10}$.

Najmniejszy odsetek zwolenników niepodległości na Łotwie wiązał się z układem narodowościowym tego kraju i niezadowoleniem części mieszkańców z pozbawienia prawa głosowania wojskowych, niektórych kategorii pracowników MSW oraz marynarzy przebywających za granicami kraju. Podobne zjawiska wystąpiły w Estonii na obszarach zamieszkałych przez ludność nieestońską, a więc w północno-wschodniej części kraju, gdzie odsetek zwolenników niepodległości był o wiele niższy niż w skali państwa: w Narwie (zamieszkałej w 4 proc. przez Estończyków) - 25 proc. zwolenników niepodległości, w Kotla-Järve - 46 proc., w Sillimäe - 11 proc.

W marcu 1990 r. w Estonii zostały przeprowadzone wybory do parlamentu, który przywrócił nazwę - Republika Estońska oraz przyjął rezolucję $O$ politycznym statusie Estonii. Bardzo istotne znaczenie miało także uchwalenie 16 maja 1990 r. ustawy znoszącej obowiązywanie w Estonii jakichkolwiek aktów prawnych ustanowionych przez władze radzieckie. Ostatecznie pełną niezależność państwo estońskie uzyskało W sierpniu $1991 \mathrm{r}^{11}$

Decyzje parlamentów państw bałtyckich o zorganizowaniu własnych głosowań spotkały się ze zdecydowanym sprzeciwem władz ZSRR. Rada Najwyższa ZSRR w uchwale z 25 lutego 1991 r. uznała referenda bałtyckie w sprawie samodzielności republik za bezprawne, gdyż nie zawierały

9 M. Narbut, 90 procent za niepodległościq, „Rzeczypospolita” 1991, nr 36, s. 1 .

10 S. White, G. Gill, D. Slider, The Politics of Transition: Sharping a Post-Soviet Future, Cambridge University Press, New York-Victoria 1993, s. 89.

11 T. Mikulski, Estonia w procesie akcesji do Unii Europejskiej (1990-2000), „Przegląd Zachodni” 2002, nr 1, s. 65. 
odpowiedzi na pytanie postawione w głosowaniu ogólnozwiązkowym, przewidzianym na 17 marca $1991 \mathrm{r}^{12}$

$\mathrm{Na}$ ten dzień zaplanowano przeprowadzenie jedynego w dziejach Związku Radzieckiego referendum.

Idea referendum ogólnozwiązkowego w ZSRR wypłynęła od prezydenta M. Gorbaczowa. Na IV Zjeździe Deputowanych Ludowych ZSRR, 24 grudnia 1990 r. wystapił on z inicjatywą ustawodawczą o przeprowadzeniu referendum w sprawie odrodzenia federacji. Zjazd przychylił się do tej inicjatywy i podjął uchwałę o przeprowadzeniu referendum ogólnozwiązkowego o zachowaniu odnowionego związku jako federacji suwerennych socjalistycznych republik. Uchwała wskazywała, że zachowanie jednego państwa związkowego stanowi ważny problem życia państwowego, dotyczy interesów każdego człowieka, całej ludności Związku Radzieckiego, stąd decyzja o przeprowadzeniu głosowania ${ }^{13}$.

Podstawę prawną przeprowadzenia referendum stanowiła ustawa o głosowaniu ludowym ZSRR, uchwalona przez Zjazd Deputowanych Ludowych ZSRR 27 grudnia 1990 r. $^{14}$

Pierwsze pytanie związane było z reformami odnowienia federacji radzieckiej. Natomiast drugie pytanie dotyczyło wprowadzenia urzędu prezydenta. Pytanie: Czy uważasz za niezbędne zachowanie Związku Socjalistycznych Republik Radzieckich jako odnowienia federacji równoprawnych, suwerennych republik, w której będą w pełni zagwarantowane prawa i wolności człowieka każdej narodowości?

Na drugie pytanie dotyczące ustanowienia urzędu prezydenta wybieranego w wyborach bezpośrednich spośród 75,09 proc. głosujących za opowiedziało się 71,38 proc.

Po odzyskaniu niepodległości przed państwami bałtyckimi stanęło pytanie o zasadniczym znaczeniu dla dalszego ich rozwoju. Czy pozostać w ścisłym związku z krajami powstałymi po rozpadzie ZSRR, czy też szukać ściślejszych związków z ówczesną EWG, Skandynawią lub innymi krajami. Zarówno Litwa, jak i Łotwa i Estonia zdecydowanie odrzuciły perspektywę przystapienia do Wspólnoty Niepodległych Państw.

12 J. Zieliński, Instytucjonalizacja przemian ustrojowych na Litwie, Lotwie $i$ Estonii, Warszawa 2004, s. 133.

13 E. Zieliński, Referendum $w$ Rosji, w: Referendum $w$ Polsce $i w$ Europie Wschodniej, red. M. T. Staszewski, D. Waniek, Warszawa 1996, s. 152.

14 Postanowlenije Wierchownogo Sovieta SSSR o prowiedieniu riefierenduma SSSR po woprosu o sochranieniju SSSR, „Izwiestija” 18 stycznia $1991 \mathrm{r}$. 
Podstawowe znaczenie w podjęciu takiej decyzji miała obawa, że organizacja ta będzie „nową formą ZSRR” służącą zachowaniu dominacji Moskwy w krajach postradzieckich. Ściślejszym zaś związkom z Rosją nie sprzyjały także różne problemy wynikające z wcześniejszych przynależności tych państw do ZSRR. Chodzi przede wszystkim o sprawę mniejszości rosyjskich, statusu oddziałów byłej armii radzieckiej stacjonującej na Litwie, Łotwie i Estonii oraz dostawy surowców energetycznych z Rosji ${ }^{15}$.

Nowe państwa, ogłaszając suwerenność w granicach republikańskich odziedziczyły po republikach radzieckich zadawnione konflikty etniczne oraz problemy będące skutkiem masowych deportacji ludności w okresie stalinowskim ${ }^{16}$. Państwa bałtyckie po uzyskaniu niezależności przyjęły tezę, iż stanowią one kontynuację państwowości międzywojennej ${ }^{17}$.

W państwach bałtyckich, Litwie, Łotwie i Estonii wcielonych przymusowo do ZSRR, podstawę do przeprowadzenia referendum stanowiła ustawa o głosowaniu ludowym, uchwalona przez Zjazd Deputowanych Ludowych ZSRR 27 grudnia 1990 r. Ustawa ta przewidywała, że referendum staje się prawomocne jeżeli w głosowaniu uczestniczy więcej niż połowa uprawnionych do głosowania obywateli zarejestrowanych na listach i za przedmiotem referendum opowiedziała się ponad połowa obywateli uczestniczących w głosowaniu ${ }^{18}$.

Rzecznik prasowy prezydenta ZSRR Witalij Inatienko stwierdził, że M. Gorbaczow przyjął ze spokojem wyniki plebiscytów w Estonii i na Łotwie, traktując je jako wskaźnik nastrojów społecznych w republikach bałtyckich. Zdaniem prezydenta plebiscyty nie miały żadnej normy prawnej ${ }^{19}$.

Podobnie postapiły republiki zakaukaskie: Armenia i Gruzja. Armenia postawiła kwestię niepodległości, za którą opowiedziało się 99 proc. mieszkańców. Gruzja poddała pod głosowanie sprawę przywrócenia niepodległości. W głosowaniu 99 proc. obywateli wypowiedziało się za

15 P. Wawrzyk, Dażenia niepodległościowe państw bałtyckich w latach 1985-1991, „Stosunki Międzynarodowe” 1995, nr 17, s. 156.

16 B. Górowska, Tworzenie struktury władzy państwowej republik, w: Przeobrażenia ustrojowe $w$ republikach byłego ZSRR, red. E. Zieliński, Warszawa 1992, s. 118 .

17 W. Czapliński, Zmiany terytorialne w Europie Środkowej $i$ Wschodniej. Ich skutki międzynarodowe (1990-1992), Warszawa 1997, s. 33.

18 E. Zieliński, Referendum $w$ Rosji..., op. cit., s. 153.

19 (C), Gorbaczow o plebiscytach, ,Rzeczypospolita” 1991, nr 55, s. 9. 
niepodległością. Wyniki referendów stały się legitymacją do ogłoszenia niezawisłości republik.

W roku 1991 odbyły się na Ukrainie dwa głosowania dotyczące przyszłości państwa. Pierwsze głosowanie przeprowadzono razem z radzieckim referendum ogólnozwiązkowym 17 marca. 27 lutego Rada Najwyższa Ukrainy głosami 227 do 32 podjęła uchwałę o dodaniu do referendum jeszcze jednego pytania dotyczącego suwerenności Ukrainy. $\mathrm{Z}$ inicjatywy narodowych komunistów do ogólnozwiązkowego referendum 17 marca 1991 r., dołączone zostało w granicach republiki dodatkowe pytanie: Czy zgadza się Pan/Pani na to, aby Ukraina była częścia Zwiazku Radzieckiego Suwerennych Państw na podstawie Deklaracji Niezależności Ukrainy? (kontrolowane przez opozycję rady trzech obwodów galicyjskich dołączyły jeszcze trzecie pytanie: Czy chce Pan/Pani aby Ukraina stała się niepodległym państwem?). Wyniki referendum dostarczyły „narodowym komunistom” nowej legitymacji, chociaż społeczeństwo na Ukrainie okazało się bardziej konserwatywne niż w innych republikach ${ }^{20}$.

Frekwencja na Ukrainie przekroczyła 83 proc. Na pierwsze pytanie, czy obywatele Ukrainy życzą sobie zachowania ZSRR w zreformowanym kształcie, 70 proc. wszystkich obywateli opowiedziało się za tym postulatem.

Na drugie pytanie, czy mieszkańcy Ukrainy życzą sobie pozostawienia Ukrainy, na określonych w Deklaracjach o suwerenności zasadach, w ZSRR odpowiedziało „tak” 80 proc. W obwodach lwowskim, tarnopolskim i iwano-frankowskim (dawne woj. Stanisławowskie) na miejscowe trzecie pytanie, czy obywatele Ukrainy życzą sobie całkowitej niepodległości Ukrainy „tak” odpowiedziało aż 88 proc. głosujących ${ }^{21}$.

Wyniki referendum wyraźnie pokazały nie tylko chęć mieszkańców Ukrainy do zachowania ZSRR, ile uznanie realiów przynależności do niego Ukrainy w tamtym czasie. Najtrudniejsza sytuacja zaistniała na Krymie, gdzie Rosjanie stanowili 67 proc. ogółu ludności, Ukraińcy zaś 26 proc, spośród których język ukraiński podało jako ojczysty 47 proc. ${ }^{22}$

1 grudnia 1991 r. odbyło się kolejne referendum w sprawie poparcia niepodległości. Frekwencja wyniosła ponad 84 proc., za opowiedziało

20 J. Hrycak, Historia Ukrainy 1772-1999, Lublin 2000, s. 319.

21 A. J. Madera, Między Rosja a Europq. Ukraina na rozdrożu, Rzeszów 2000, s. 38 .

22 Ibidem, s. 39. 
się ponad 90 proc. obywateli (najwięcej w woj. Tarnopolskim 98,67 proc., najmniej na Krymie 54,19 proc.) $)^{23}$.

Jedynie na Krymie przy frekwencji ponad 50 proc., za niepodległością opowiedziało się tylko 54 proc. głosujących ${ }^{24}$. Referendum stało się ostatnim gwoździem do trumny Związku Radzieckiego, wcześniej 24 sierpnia parlament Ukrainy proklamował niepodległość ${ }^{25}$.

Wyniki grudniowego referendum niejako uprawomocniające sierpniową decyzję Rady Najwyższej ułatwiły międzynarodowe uznanie państwowości ukraińskiej, przyspieszyły porozumienie z sąsiadami i potwierdziły pokojowy charakter ukraińskiej drogi do niepodległości.

Tabela 1

Wyniki referendów w kwestii niepodległości z 1991 r.

\begin{tabular}{||l|l|c|c|c||}
\hline \multirow{2}{*}{ Republika } & \multicolumn{1}{|c|}{ Data } & \multirow{2}{*}{$\begin{array}{c}\text { Frekwencja } \\
\text { (proc.) }\end{array}$} & \multicolumn{2}{c||}{ Glosujących (proc.) } \\
\cline { 4 - 5 } & & 84,43 & 90,47 & Nie \\
\hline Litwa & 9 lutego & 87,56 & 73,68 & 5,56 \\
Lotwa & 3 marca & 82,96 & 73,73 & 24,69 \\
Estonia & 3 marca & 90,53 & 99,08 & 0,51 \\
Gruzja & 31 marca & 95,05 & 99,31 & 0,46 \\
Armenia & 21 września & b.d. & 94,10 & b.d. \\
Turkmenistan & 26 października & 84,20 & 90,30 & 7,60 \\
Ukraina & 1 grudnia & 95,27 & 99,58 & 0,24 \\
Azerbejdżan & 29 grudnia & b.d. & 98,20 & b.d. \\
Uzbekistan & 29 grudnia & \multicolumn{2}{|c}{} \\
\hline
\end{tabular}

Źródło: S. White, G. Gill, D. Slinder, The Politics of Transition: Shaping a Post Soviet Future, New York-Victoria 1993, s. 89.

\section{Bałkany}

W latach 1990-2006 referenda w kwestii niepodległości przeprowadziły republiki dawnej Jugosławii. W 1990 r. ludność Słowenii (88 proc.) wypowiedziała się za niepodległością. W 1991 r. społeczeństwo Chorwacji (93 proc.) opowiedziało się za niezawisłością. Również w $1991 \mathrm{r}$. ludność Macedonii (95 proc.) opowiedziała się za niepodległością.

23 W. Kułyk, Ukraińska rewolucja 1917-1991, „Dziś” 1992, nr 8, s. 32.

24 A. J. Madera, Między Rosja..., op. cit., s. 41.

25 J. Hrycak, Historia Ukrainy..., op. cit., s. 322. 
W 1992 r. ludność Bośni i Hercegowiny (63 proc.) głosowali za niezależnością republiki. Ludność Czarnogóry (95 proc.) początkowo zadecydowała o pozostawieniu republiki wraz z Serbią we wspólnym państwie Jugosławii, jednak w 2006 r. podjęto decyzję o „rozwodzie”.

Referenda republik jugosłowiańskich potwierdziły dążenia ich narodów do stworzenia wspólnot narodowych i uniezależnienia się od scentralizowanej federacji.

Pod koniec lat 80. doszło do eksplozji dążeń niepodległościowych i zmian ustrojowych. Najsilniejsze tendencje odśrodkowe wykazały Słowenia i Chorwacja ${ }^{26}$. Oba państwa wzmogły dążenia do przekształcenia systemu federalnego Jugosławii w system konfederacyjny wzmacniający autonomię republiki. Natrafiały one na sprzeciw dominującej w Jugosławii Serbii.

Republika Słowenii jest państwem, które wyrosło z woli narodu wyrażonej bezpośrednio w głosowaniu w sprawie niepodległości i suwerenności Republiki w 1990 r. Referendum odbyło się 23 grudnia 1990 r. w sprawie niepodległości Republiki. Zarządziła je Skupsztina Republiki Słowenii. W głosowaniu 88,5 proc. uprawnionych opowiedziało się za niepodległością Republiki, a tylko 4,0 proc. było przeciw. Frekwencja sięgała 93,5 proc. Społeczeństwo zadecydowało o doniosłej sprawie bytu narodowego i powstania państwa narodowego ${ }^{27}$. Stosunek partii politycznych do referendum niepodległościowego charakteryzował się dużą jednolitością. W grudniu 1990 r. partie polityczne porozumiały się i prezentowały wspólne stanowisko w referendum w sprawie niepodległości republiki. Wysoki wynik poparcia dowodzi zespolenia sił i rozwinięcia wspólnego działania. Podobnie jednolite stanowisko popierające zajmują partie wobec referendum w sprawie przystąpienia do UE. Sprawy te traktują jako nadrzędne wobec kwestii wewnętrznych, gdzie wykazują zróżnicowane stanowiska ${ }^{28}$.

Chorwacja. 25 czerwca 1991 r. parlament chorwacki w oparciu o art. 140 Konstytucji przyjął „Deklarację o Ogłoszeniu Suwerenności

26 J. Stańczyk, Przeobrażenia międzynarodowego układu sił w Europie na przełomie lat osiemdziesiatych i dziewięćdziesiatych, Warszawa 1999, s. 136.

27 E. Zieliński, Referendum w Czechach, Stowacji, Stowenii i na Węrzech, w: E. Zieliński, I. Bokszczanin, J. Zieliński, Referendum w państwach Europy, Warszawa 2003, s. 67; zob.: J. J. Wiatr, Stowenia - przyktad udanej transformacji, Warszawa 1998, s. 17-20.

28 Ibidem, s. 76. 
i Niepodległości Republiki Chorwacji”29. Podstawą tej deklaracji było referendum z 19 maja 1991 r. w którym zdecydowana większość mieszkańców Chorwacji opowiedziała się za suwerennością ich republiki (ponad 90 proc.).

Republika Chorwacji nie pozostanie w Jugosławii jako zjednoczonym kraju federacyjnym - głosi oświadczenie, w którym podkreśla się zarazem, że Republika Chorwacji jako suwerenne i niepodległe państwo może przyłączyć się wraz z innymi republikami do konfederacji suwerennych państw ${ }^{30}$.

Obydwie deklaracje (a zwłaszcza chorwacka) przesądziły o rozpadzie federacji. Zawiła struktura narodowościowa obszarów Jugosławii spowodowała przy tym, że w marcu 1991 r. chorwaccy Serbowie ogłosili secesję z Chorwatami i powołali niezależną jednostkę terytorialną w ramach federacji jugosłowiańskiej - Krajinę.

Referenda w kwestiach niepodległościowych zapowiedziały pozostałe republiki, zaś Słowenia i Chorwacja przyśpieszyły swe decyzje o wydzieleniu się (a nie oderwaniu) z SFRJ, podejmując je w głosowaniach parlamentarnych 25 czerwca 1991 r. uznając się wzajemnie za pełnoprawne podmioty prawa międzynarodowego i apelując o szerokie międzynarodowe uznanie ich państwowości ${ }^{31}$.

W styczniu 1992 r. Chorwacja została uznana przez społeczność międzynarodową, a 22 maja wraz ze Słowenią oraz Bośnią i Hercegowiną przyjęta do ONZ. Musiała jednak wprowadzić poprawki do konstytucji, gwarantujące prawa mniejszościom narodowym ${ }^{32}$.

Najwcześniej - bo już w końcu 1991 r. i na początku 1992 r. uznały Słowenię i Chorwację Austria, RFN, Watykan i EWG. One też najbardziej wpływały na oba kraje, by wyszły z federacji ${ }^{33}$.

Slobodan Milošević oficjalnie akceptował niepodległość Słowenii i Chorwacji i nie miał nic przeciwko temu, aby obie republiki poszły drogą suwerenności. Już wcześniej przyznał, to podczas rozmów w Mo-

29 Konstytucja Republiki Chorwacji, Wstęp A. i L. Garliccy, Warszawa 1995, s. 7.

30 (PAP), Chorwacja ogłasza niepodległość, „Rzeczypospolita” 1991, nr 125 , s. 1 .

31 J. Stańczyk, Przeobrażenia międzynarodowego uktadu..., op. cit., s. 137.

32 L. Podhorodecki, Jugosławia. Dzieje narodów, państw i rozpad federacji, Warszawa 2000, s. 201.

33 M. Tanty, Bałkany w XX w. Dzieje polityczne, Warszawa 2003, s. 349. 
skwie z M. Gorbaczowem, oświadczając, że każdy naród jugosłowiański ma prawo do samookreślenia się e $^{34}$.

Tym samym została podważona ostatecznie zasada funkcjonowania państwa federalnego w oparciu o serbsko-chorwacką zgodę na istnienie jednolitego państwa. Rozpoczął się proces rozpadu federacji jugosłowiańskiej ${ }^{35}$. Wszelkie apele, również ze strony społeczności międzynarodowej na rzecz utrzymania państwa federalnego okazały się pozbawione wartości. Paradoksalnym pozostaje fakt, że to właśnie wolne wybory, które odbyły się w 1990 r. w Słowenii i Chorwacji rozpoczęły bezpośrednio ten proces. Wtedy bowiem doszło w obydwu tych krajach do zwycięstwa partii i polityków o orientacji nacjonalistycznej, którzy opowiadali się w jednoznaczny sposób za odłączeniem się tych dwu państw od federacji jugosłowiańskiej ${ }^{36}$.

W Bośni i Hercegowinie 15 października 1991 r. parlament przyjął memorandum o suwerenności, a 29 lutego-1marca 1992 r. większość muzułmanów i Chorwatów opowiedziała się za niepodległością (referendum), w efekcie czego 3 marca 1992 r. ogłoszono niepodległość. W głosowaniu frekwencja wyniosła 62,45 proc., za niepodległością opowiedziało się 99,69 proc. głosujących. Bośniaccy Serbowie, którzy zbojkotowali referendum niepodległościowe, ogłosili 9 stycznia 1992 r. powstanie Serbskiej Republiki Bośni i Hercegowiny, która miała objąć 2/3 powierzchni dotychczasowej republiki w jej częściach północnej i wschodniej ${ }^{37}$. Po załamaniu się sojuszu chorwacko-muzułmańskiego 4 lipca 1992 r. powstało, proklamowane przez bośniackich Chorwatów, państwo Chorwacka Wspólnota Herceg-Bośni. W wyniku referendum z 15-16 maja 1993 r. bośniaccy Serbowie odrzucili zachodni plan podziału Bośni i Hercegowiny na okręgi autonomiczne, pozostając przy decyzji utworzenia Serbskiej Republiki Bośni i Hercegowiny, do której przystapienie zadeklarowała na mocy referendum z 19-20 lipca $1993 \mathrm{r}$.

34 M. Korzeniewska-Wiśniewska, Serbia pod rzqdami Slobodana Milošewicia, Kraków 2008, s. 128.

35 Zob.: M. Mizerski, Geneza i rozpad ustroju federalnego bytych socjalistycznych państw europejskich, Toruń 1996, s. 24; zob. W. Czapliński, Zmiany terytorialne $w$ Europie..., op. cit., s. 35-39.

36 F. Gołębiewski, Etniczne podłoże konfliktów na terenie byłej Jugosławii, w: Nacjonalizm. Konflikty narodowościowe w Europie Środkowej $i$ Wschodniej, red. S. Helnarski, Toruń 2001, s. 341.

37 M. Korzeniewska-Wiśniewska, Serbia pod rzqdami..., op. cit., s. 134. 
republika Serbskiej Krajiny (dotąd na obszarze Chorwacji: 30 proc. jej obszaru $)^{38}$.

Podobnie było w Macedonii, w której zorganizowano referendum 8 września 1991 r. Macedończycy zdecydowaną większością głosów poparli pomysł odseparowania się od Jugosławii. Frekwencja w głosowaniu wyniosła 71 proc., za niezależnością państwową opowiedziało się 95 proc. głosujących ${ }^{39}$. Referendum zostało zbojkotowane przez mieszkających Albańczyków, którzy stanowili ok. 23 proc. społeczności Macedonii $^{40}$. Niepodległość proklamowano 18 września $1991 \mathrm{r}^{41} 17$ listopada 1991 r. prezydent Kiro Gligorov ogłosił powstanie suwerennego państwa - Republiki Macedonii, a parlament przyjął nową konstytucję. Tym samym Macedonia wystapiła $z$ federacji jugosłowiańskiej ${ }^{42}$.

Kosowo. W lipcu 1990 r. zdominowany przez Albańczyków parlament prowincji ogłosił deklarację niepodległości, uznaną tylko przez Albanię ${ }^{43}$. 30 września 1991 r. odbyło się referendum, w którym około 99 proc. uprawnionych do głosowania mieszkańców Kosowa opowiedziało się za niepodległością ${ }^{44}$. Doszło do proklamowania tzw. Niezależnej Republiki Kosowa. Wywołało to protesty ze strony serbskiej. W tym czasie większość państw ówczesnej Europejskiej Wspólnoty Gospodarczej opowiadała się za przywróceniem regionowi Kosowa statusu okręgu autonomicznego ${ }^{45}$.

17 lutego 2008 r. Parlament Kosowa, protektoratu administrowanego przez ONZ - w porozumieniu z Waszyngtonem i wiodącymi państwami UE - ogłosił w tymczasowej stolicy Prisztinie niepodległość. Przeciwko deklaracji niepodległości ostro zaprotestowały Serbia i Rosja ${ }^{46}$. Oba

38 J. Stańczyk, Przeobrażenia międzynarodowego układu..., op. cit., s. 140.

39 M. Musiał-Karg, Referenda w państwach europejskich, Toruń 2008, s. 202.

40 Zob. J. Stawowy-Kawka, Historia Macedonii, Wrocław-Warszawa-Kraków 2000, s. 297-303.

41 L. Podhorodecki, Jugostawia. Dzieje..., op. cit., s. 202.

42 J. Stawowy-Kawka, Historia..., op. cit., s. 293.

43 F. Gołębiewski, Bałkany w latach 1989-1993. Problemy bezpieczeństwa regionalnego, Warszawa 1994, s. 8.

44 J. Stańczyk, Przeobrażenia międzynarodowego układu..., op. cit., s. 141.

45 S. Wojciechowski, Integracja $i$ dezintegracja Jugosławii na przełomie XX i XXI w., Poznań 2002, s. 186; zob.: A. Balcer, Kosowo - kwestia ostatecznego statusu, Prace Ośrodka Studiów Wschodnich, Warszawa 2003, nr 10, s. 18-33.

${ }_{46}$ Zob. A. Widzyk, Bośniaccy Serbowie groża referendum $w$ sprawie niepodległości, 23.02.2008, http://new-arch.rp.pl/artykul/754153.html, 1.06.2010; K. Zuchowicz, Serbowie w referendum: Kosowo jest nasze. Unia: to ciagle sprawa do negocjacji, http://new-arch.rp.pl/artykul/647027.html, 1.06.2010. 
państwa opowiadają się za podziałem Kosowa. Po ogłoszeniu deklaracji niepodległości doszło do rozruchów i demonstracji, które pokazały, że Serbia nie akceptuje oderwania się swojej prowincji ${ }^{47}$.

W Czarnogórze przedmiotem pierwszego referendum było pozostanie we wspólnocie państwowej z Serbią. Odbyło się ono 1 marca 1992 r. $\mathrm{Na} 66$ proc. uczestniczących w głosowaniu 95,9 proc. wypowiedziało się za propozycją pozostania $\mathrm{w}$ federacji. Wynik ten przesądził o stworzeniu federacji Serbii i Czarnogóry pod nazwą Federacyjna Republika Jugosławii. Wola jedności, zadeklarowana przez większość ludności Czarnogóry, miała więc decydujące znaczenie dla pozostania w wielonarodowej federacji ${ }^{48}$.

W 1991 r. Słowenia, Chorwacja i Macedonia kolejno ogłaszały niepodległość i odrywały się od Jugosławii, rok później poszła ich śladem Bośnia i Hercegowina. Jedna tylko Czarnogóra zdecydowała się pozostać z Serbią w ramach Jugosławii (zwanej teraz Nową albo Trzecią). Czarnogórcy walczyli po stronie Serbów w wojnach w Chorwacji i Bośni 1991-1995, biorąc m.in. udział w zniszczeniu chorwackiego Dubrownika.

Na decyzję Czarnogórców miał wpływ szereg czynników: bliskość językowa, kulturowa i religijna z Serbami, mały potencjał (rozmiar i ludność) Czarnogóry, wreszcie polityczna bliskość przywódców (w obu republikach władzę utrzymała lewica). Nie bez znaczenia było też czarnogórskie pochodzenie serbskiego prezydenta Miloszevićia.

$\mathrm{Z}$ biegiem lat sytuacja uległa zmianie. Z czasem wielkoserbski nacjonalizm zyskiwał w Czarnogórze coraz więcej wrogów. Podobnie niepopularny stał się prezydent Jugosławii Miloszević - od 1996 r. (próba sfałszowania wyborów samorządowych) rządzący już jawnie po dyktatorsku i skłócony z przywództwem Czarnogóry.

W 2003 r. Jugosławia została przemianowana na Serbię i Czarnogórę uzgodniono przy tym, że za 3 lata odbędzie się referendum w sprawie niepodległości tej ostatniej ${ }^{49}$. Nadmienić tu trzeba, że Unia Europejska niechętnie widziała rozpad federacji, bojąc się dalszej destabilizacji na

47 G. Besier, K. Stokłosa, Europa dyktatur, Warszawa 2009, s. 515.

48 E. Zieliński, Referendum w państwach Europy Środkowej $i$ Wschodniej, w: E. Zieliński, I. Bokszczanin, J. Zieliński, Referendum w państwach Europy, Warszawa 2003, s. 208.

49 Zob.: J. Wojnicki, Przeobrażenia ustrojowe państw postjugosłowiańskich (1990-2003), Pultusk 2003, s. 68-71. 
Bałkanach i nie chcąc dawać przykładu dla Kosowa (wtedy już okupowanego przez NATO, ale formalnie pozostającego częścią Serbii). Z tego samego powodu sprzeciwiała się secesji Rosja - tradycyjna sojuszniczka Serbii na Bałkanach.

Czarnogóra coraz śmielej domagała się niepodległości, a 7,5-milionowej Serbii trudno było traktować liczącą zaledwie 620 tysięcy obywateli republikę jako partnera. Umowa miała obowiązywać co najmniej trzy lata, do lutego 2006 roku. Po upływie tego czasu Belgrad i Podgorica miały zdecydować czy pozostaną razem, czy się rozejdą ${ }^{50}$. Ku przerażeniu Serbii Czarnogóra zażądała rozwodu ${ }^{51}$.

W lutym 2005 r. władze Czarnogóry zaproponowały zlikwidowanie Unii państwowej i utworzenie w jej miejsce dwóch niezależnych państw. Przedstawiony projekt zakładał powstanie dwóch instytucji wspólnych: parlamentu oraz komisji wspólnoty niezależnych państw. Przedstawiciele Czarnogóry zadeklarowali, że republika odda Serbii miejsce federalnego państwa we wszystkich organizacjach międzynarodowych, a Czarnogóra będzie ubiegać się o członkostwo jako oddzielny organizm państwowy ${ }^{52}$.

W referendum 2006 roku narzucono Czarnogórcom warunek: wynik będzie wiążący, jeśli za niepodległością opowie się przynajmniej 55 proc. głosujących. Taki zapis miał uchronić przed secesją wbrew woli niemal połowy ludności, stanowił jednak dość oryginalne rozwiązanie. W imieniu UE warunek ten przedstawił szwedzki dyplomata. Zirytowany premier Czarnogóry Milo Djukanović zauważył, że gdyby taki sam próg obowiązywał w referendum nt. wstąpienia Szwecji do UE w 1995 r., to nie byłoby jej dzisiaj w tej organizacji (za wstapieniem do UE głosowało 53 proc. Szwedów) ${ }^{53}$.

Początkowo premier nie godził się na takie rozwiązanie, mówiąc, że jest ono niesprawiedliwe - większość to przecież 50 plus jeden głos. W rzeczywistości obawiał się, że przeciwników federacji z Serbią może nie być aż tylu ${ }^{54}$.

50 Zob.: A. Balcer, Czarnogóra - przed wyborami parlamentarnymi, „Tydzień na Wschodzie" 2001, nr 16, s. 7-10.

51 M. Szulc, Czarnogóra bez Serbii, 23.05.2006, RP.pl, http://new-arch.rp.pl/artykul/617218.html, 1.06.2010.

52 K. Krysieniel, J. Wojnicki, Partie i systemy partyjne państw byłej Jugosławii, Pułtusk-Warszaw 2009, s. 162.

53 M. A. Wirtel, Czarnogóra - znowu niezależna, 29.04.2007, Psz.pl, http://www.psz.pl/ tekst-4424/Michal-Andrzej-Wirtel-Czarnogora-znowu-niezalezna, 1.06.2010.

54 M. Szulc, Czarnogóra..., op. cit. 
Kampania była niezwykle wyrównana, za niepodległością optowali zwolennicy M. Djukanovicia. Z kolei za utrzymaniem więzi z Serbią optowali zwolennicy proserbskiego ruchu Pretraga Bulatovicia. Rząd Serbii kierowany przez Vojislava Koštunicę podkreślał natomiast korzyści dla Czarnogóry z pozostania w związku z Serbią ${ }^{55}$.

Kampania propagandowa obu stron była intensywna, ale - jak na Bałkany - spokojna. Tysiące Czarnogórców przyjechały na dzień głosowania zza granicy. Głosowanie 21 maja 2006 r. oceniono jako uczciwe i przebiegające bez większych zakłóceń. Po podliczeniu głosów okazało się, że większość 55 proc. została minimalnie przekroczona (ledwie o 2 tys. głosów), Czarnogóra stała się więc na powrót niepodległym państwem (3 czerwca 2006).

Na wyniku zaważyły właśnie głosy mniejszości narodowych - Albańczyków i Bośniaków, którzy po wojnach bałkańskich mieli jak najgorsze doświadczenia z Serbami i woleli żyć w odrębnej republice.

Atutem nowego państwa jest kwestia integracji europejskiej - bez Serbii będzie Czarnogórze o wiele łatwiej zintegrować się z UE. Jest ona dużo mniejsza, więc będzie jej łatwiej przyjąć unijne standardy.

Niewątpliwie dobrym znakiem jest też sposób wybicia się na niepodległość - przy pomocy kartki wyborczej, nie zaś karabinów. Trzeba też pamiętać, że przeciw niepodległości głosowało 45 proc. obywateli, 1/3 ludności uważa się za Serbów, a 1/6 to mniejszości islamskie. Rodzi to pytanie o lojalność tej części ludności wobec młodego państwa i potencjalne konflikty wewnętrzne ${ }^{56}$.

Zaraz po tym, gdy czarnogórski parlament proklamował niepodległość, jego przewodniczący Ranko Krivokapić określił najbardziej pilne priorytety Czarnogóry: natychmiastowe rozpoczęcie rozmów w sprawie członkostwa w ONZ i innych międzynarodowych organizacjach (Czarnogóra jest 192 członkiem ONZ od 29.06.2008 r.), do których należała federacja Serbii i Czarnogóry. Potwierdził też wcześniejsze deklaracje, że celem jego kraju jest wejście do NATO i Unii Europejskiej.

Proklamacja niepodległości Czarnogóry to kolejny etap postępującego od 1991 roku rozpadu Jugosławii, który zaczął się od secesji Chor-

${ }_{56}^{5}$ K. Krysieniel, J. Wojnicki, Partie i systemy partyjne..., op. cit., s. 120.

56 M. A. Wirtel, Czarnogóra..., op. cit. 
wacji i Słowenii. Na mapie Europy przybył kraj wielkości województwa lubuskiego, w którym mieszka tylu ludzi, co we Wrocławiu ${ }^{57}$.

Z gratulacjami dla Czarnogórców pierwsze pospieszyły republiki, którym wcześniej udało się wyrwać spod kontroli Serbów: Słowenia, Bośnia i Hercegowina, Chorwacja. A także polskie $\mathrm{MSZ}^{58}$.

Przyszłość republik dawnej Jugosławii, a zwłaszcza ich wzajemne stosunki, zależeć będą od umocnienia w nich demokracji i od postępów pojednania. Rozpad tego państwa uwarunkowany był przede wszystkim niespójnością federacji i rosnącymi rozbieżnościami interesów, a także emocjami zamieszkujących ją narodów ${ }^{59}$.

Referendum może sprowadzać się nie tylko do czynnika aprobaty przedsięwzięć, ale także służyć jako czynnik korygujący działania elit rządzących ${ }^{60}$.

W stosunkach między społeczeństwem a władzą publiczną częściej pojawiają się ciała pośrednie, w postaci ugrupowań politycznych i różnych organizacji, które prowadzą do wyłączania jednostek i usiłowania zastępowania ich w pośrednictwie. Ludzie czują naturalną potrzebę osobistego wypowiedzenia się i manifestowania podmiotowości politycznej. Referendum jest instytucją służącą wypowiedzeniu się obywateli w określonej kwestii przedstawianej do rozstrzygnięcia ${ }^{61}$. Decydowanie o własnym losie narodowym w drodze referendum stało się powszechne nie tylko w przypadku mieszkańców krajów bałtyckich i bałkańskich, ale także innych narodów. Wyrażanie woli ludzi w głosowaniu o chęci przynależności państwowej i formie bytu narodowego należy do najstarszych praktykowanych głosowań. W najnowszych dziejach elity narodowe krajów bałtyckich i bałkańskich oraz Ukrainy skrzętnie wykorzystały sposobność sytuacji konfliktowych w strukturach federalnych i sprzyjające okoliczności odwołania się do narodu. Referendum stało się instrumentem wyrażenia woli narodu i opowiedzenia się za niepodległością. Ta forma odwołania do narodu okazała się skuteczna w przypadku spo-

57 Aksamitny rozwód z Serbami, 5.06.2006, RP.pl, http://new-arch.rp.pl/artykuł/ 619626.html, 1.06.2010.

58 Niepokojacy precedens, 23.05.2006, Rp.pl, http://new-arch.rp.pl/artyku1/ 617203.html, 1.06.2010.

59 J. J. Wiatr, Europa pokomunistyczna: przemiany państwa i społeczeństwa po 1989 r., Warszawa 1989, s. 106.

60 E. Zieliński, Referendum w państwach Europy Środkowej i Wschodniej, s. 203.

61 Ibidem, s. 204. 
łeczności o znacznym poczuciu świadomości narodowej i przekonaniu o konieczności odrodzenia bytu państwowego w ramach suwerennych państw. We wszystkich krajach bałtyckich i bałkańskich oraz na Ukrainie wyniki referendum potwierdzały wolę i chęć niezawisłego bytowania $w$ ramach państwa narodowego ${ }^{62}$.

Tabela 2

Referenda niepodległościowe w Europie (1991-2006)

\begin{tabular}{||l|c|c|c|c|l||}
\hline \multicolumn{1}{|c|}{ Państwo } & $\begin{array}{c}\text { Data } \\
\text { referendum }\end{array}$ & $\begin{array}{c}\text { Frekwencja } \\
\text { \% }\end{array}$ & Tak \% & Nie \% & Rezultat \\
\hline Bośnia i Hercegowina & 1.03 .1992 & 62,45 & 99,69 & 0,31 & przyjęte \\
\hline Chorwacja & 19.05 .1991 & 84,94 & 93,24 & 6,76 & przyjęte \\
\hline Czarnogóra & 1.03 .1992 & 66,00 & 4,10 & 95,90 & odrzucone \\
& 25.05 .2006 & & 55,00 & 45,00 & przyjęte \\
\hline Kosowo & 30.09 .1991 & b.d. & 99,00 & 1,00 & przyjęte \\
\hline Macedonia & 8.09 .1991 & 71,85 & 95,09 & 4,91 & przyjęte \\
\hline Litwa & 9.02 .1991 & 84,74 & 93,24 & 6,76 & przyjęte \\
\hline Lotwa & 3.03 .1991 & 87,56 & 74,90 & 25,10 & przyjęte \\
\hline Estonia & 3.03 .1991 & 82,96 & 78,41 & 21,57 & przyjęte \\
\hline Ukraina & 17.03 .1991 & 83,50 & 83,50 & 16,50 & przyjęte \\
& 1.12 .1991 & 84,18 & 92,26 & 7,74 & przyjęte \\
\hline \hline
\end{tabular}

Źródło: Opracowanie własne na podstawie dostępnych danych.

\section{Bibliografia}

Anioł W., Wspótczesny nacjonalizm w Europie Środkowo-Wschodniej: podtoże, rodzaje napięć i reakcja instytucji regionalnych, w: Nacjonalizm. Konflikty narodowościowe w Europie Środkowej $i$ Wschodniej, red. S. Helnarski, Wydawnictwo Adam Marszałek, Torun 2001.

Balcer A., Czarnogóra - przed wyborami parlamentarnymi, „Tydzień na Wschodzie” 2001, nr 16.

Balcer A., Kosowo - kwestia ostatecznego statusu, Prace Ośrodka Studiów Wschodnich nr 10/2003, Warszawa.

Besier G., Stokłosa K., Europa dyktatur, Wydawnictwo Naukowe PWN, Warszawa 2009.

${ }^{62}$ Ibidem, s. 214. 
Bokszczanin I., Instytucja referendum ratyfikacyjnego w procesie integracji w Europie, w: Wymiar społeczny członkostwa Polski w Unii Europejskiej, red. T. Mołdawa, K. A. Wojtaszczyk, A. Szymański, Fundacja „Politeja”, ASPRA-JR, Warszawa 2003.

(C), Gorbaczow o plebiscytach, „Rzeczpospolita” 1991, nr 55.

Chorwacja ogłasza niepodległość, „Rzeczpospolita” 1991, nr 125.

Czapliński W., Zmiany terytorialne w Europie Środkowej i Wschodniej. Ich skutki międzynarodowe (1990-1992), Warszawa 1997.

Gołębiewski F., Bałkany w latach 1989-1993. Problemy bezpieczeństwa regionalnego, Warszawa 1994.

Gołębiewski F., Etniczne podłoże konfliktów na terenie byłej Jugosławii, w: Nacjonalizm. Konflikty narodowościowe $w$ Europie Środkowej $i$ Wschodniej, red. S. Helnarski, Wydawnictwo Adam Marszałek, Torun 2001.

Górowska B., Tworzenie struktury władzy państwowej republik, w: Przeobrażenia ustrojowe w republikach byłego ZSRR, red. E. Zieliński, Wyd. UW, Warszawa 1992.

Hrycak J., Historia Ukrainy 1772-1999, Lublin 2000.

Karski K., Proces rozpadu Zwiazku Radzieckiego, Studia i Materiały Centrum Badań Wschodnich Uniwersytetu Warszawskiego, Warszawa 1992.

Konstytucja Republiki Chorwacji, Wstęp A. i L. Garliccy, Wydawnictwo Sejmowe, Warszawa 1995.

Korzeniewska-Wiśniewska M., Serbia pod rzqdami Slobodana Milošewicia, UJ, Kraków 2008.

Krysieniel K., Wojnicki J., Partie i systemy partyjne państw byłej Jugosławii, Akademia Humanistyczna im. A. Gieysztora, Pułtusk-Warszawa 2009.

Kułyk W., Ukraińska rewolucja 1917-1991, „Dziś” 1992, nr 8.

Kwiecień R., Tożsamość Litwy, Łotwy i Estonii, Warszawa 1997.

Madera A. J., Między Rosja a Europq. Ukraina na rozdrożu, Rzeszów 2000.

Mikulski T., Estonia w procesie akcesji do Unii Europejskiej (1990-2000), „Przegląd Zachodni" 2002, nr 1 .

Mizerski E., Geneza i rozpad ustroju federalnego bylych socjalistycznych państw europejskich, Wydawnictwo Adam Marszałek, Toruń 1996.

Musiał-Karg M., Referenda w państwach europejskich, Wydawnictwo Adam Marszałek, Toruń 2008.

Nacjonalizm. Konflikty narodowościowe w Europie Środkowej $i$ Wschodniej, red. S. Helnarski, Wydawnictwo Adam Marszałek, Torun 2001.

Narbut M., 90 procent za niepodległościa, „Rzeczypospolita” 1991, nr 36.

Podhorodecki L., Jugosławia. Dzieje narodów, państw i rozpad federacji, Warszawa 2000. 
Postanowlenije Wierchownogo Sovieta SSSR o prowiedieniu riefierenduma SSSR po woprosu o sochranieniju SSSR, „Izwiestija” z dnia 18 stycznia 1991 r.

Przeobrażenia ustrojowe $w$ republikach byłego ZSRR, red. E. Zieliński, Wyd. UW, Warszawa 1992.

Referendum w Polsce i w Europie Wschodniej, red. M. T. Staszewski, D. Waniek, ISP PAN, Warszawa 1996.

Stańczyk J., Przeobrażenia międzynarodowego układu sił w Europie na przełomie lat osiemdziesiatych i dziewięćdziesiatych, ISP PAN, Warszawa 1999.

Stawowy-Kawka J., Historia Macedonii, Wrocław-Warszawa-Kraków 2000.

Szulc M., Czarnogóra bez Serbii, 23.05.2006, RP.pl, http://new-arch.rp.pl/artykul/617218.html.

Szura O., Litwa - przemiany polityczne. Dynamika systemów politycznych wybranych państw Europy Środkowej i Wschodniej, red. M. Barański, Katowice 1995.

Tanty M., Bałkany w XX w. Dzieje polityczne, Warszawa 2003.

White S., Gill G., Slider D., The Politics of Transition: Shaping a Post-Soviet Future, Cambridge University Press, New York-Victoria 1993.

Wymiar społeczny członkostwa Polski w Unii Europejskiej, red. T. Mołdawa, K. A. Wojtaszczyk, A. Szymański, Fundacja „Politeja”, ASPRA-JR, Warszawa 2003.

Wawrzyk P., Dażenia niepodległościowe państw battyckich w latach 1985-1991, „Stosunki Międzynarodowe” 1995, nr 17.

Wiatr J. J., Słowenia - przykład udanej transformacji, Wydawnictwo Naukowe Scholar, Warszawa 1998.

Widzyk A., Bośniaccy Serbowie groża referendum w sprawie niepodległości, 23.02.2008, Rp.pl, http://new-arch.rp.pl/artykul/754153.html.

Wirtel M. A., Czarnogóra - znowu niezależna, 29.04.2007, Psz.pl, http://www.psz.pl/ tekst-4424/Michal-Andrzej-Wirtel-Czarnogora-znowu-niezalezna.

Wojciechowski S., Integracja i dezintegracja Jugosławii na przełomie XX i XXI w., Wydawnictwo Naukowe Instytutu Nauk Politycznych i Dziennikarstwa UAM, Poznań 2002.

Wojnicki J., Przeobrażenia ustrojowe państw postjugosłowiańskich (1990-2003), Wyższa Szkoła Humanistyczna im. Aleksandra Gieysztora w Pułtusku, Pultusk 2003.

Zieliński E., Referendum w Czechach, Słowacji, Słowenii i na Węgrzech, w: E. Zieliński, I. Bokszczanin, J. Zieliński, Referendum w państwach Europy, Fundacja Europea: ASPRA-JR, Warszawa 2003.

Zieliński E., Referendum w państwach Europy Środkowej i Wschodniej, w: E. Zieliński, I. Bokszczanin, J. Zieliński, Referendum w państwach Europy, Fundacja Europea: ASPRA-JR, Warszawa 2003.

Zieliński E., Referendum $w$ Rosji, w: Referendum $w$ Polsce $i$ w Europie Wschodniej, red. M. T. Staszewski, D. Waniek, ISP PAN, Warszawa 1996. 
Zieliński E., Bokszczanin I., Zieliński J., Referendum w państwach Europy, Fundacja Europea: ASPRA-JR, Warszawa 2003.

Zieliński J., Instytucjonalizacja przemian ustrojowych na Litwie, Łotwie i Estonii, ASPRA-JR, Warszawa 2004.

Zuchowicz K., Serbowie w referendum: Kosowo jest nasze. Unia: to ciagle sprawa do negocjacji, RP.pl, http://new-arch.rp.pl/artykul/647027.html.

\title{
The role of referendums in the establishment of states in Europe following 1989
}

\begin{abstract}
Summary
The institution of the referendum is one of the forms of direct democracy. Referendums are understood as direct suffrage on important matters of state, or a part of its territory, that constitute the subject of the vote. In the processes of democratic transformation, outlooks on this institution of direct democracy evolve. Referendums have become a tool to express the will of the nation to choose in matters of sovereignty. This form of asking the nation has turned out to be effective for those communities with a strong sense of national identity and the belief that it is necessary for the state to be revived as a sovereign entity. The results of the referenda held in the Baltic states, in the Balkans and Ukraine have confirmed their peoples' wills to independently exist within the framework of a sovereign state.
\end{abstract}

